\title{
Estimated age of first exposure to American football and outcome from concussion
}

Jaclyn B. Caccese, PhD, Zac Houck, MS, Thomas W. Kaminski, PhD, ATC, James R. Clugston, MD, MS, CAQSM, Grant L. Iverson, PhD, Kelsey N. Bryk, MS, Jessie R. Oldham, PhD, Paul F. Pasquina, MD,

Steven P. Broglio, PhD, ATC, Thomas W. McAllister, MD, Michael McCrea, PhD, ABPP,

April Marie (Reed) Hoy, MS, ATC, Joseph B. Hazzard, Jr., EdD, ATC, Louise A. Kelly, PhD, Justus D. Ortega, PhD, Nicholas Port, PhD, Margot Putukian, MD, T. Dianne Langford, PhD, Christopher C. Giza, MD,

Joshua T. Goldman, MD, MBA, Holly J. Benjamin, MD, Julianne D. Schmidt, PhD, ATC,

Luis A. Feigenbaum, DPT, ATC, James T. Eckner, MD, MS, Jason P. Mihalik, PhD, CAT(C), ATC,

Jessica Dysart Miles, PhD, ATC, Scott Anderson, ATC, Christina L. Master, MD, Micky W. Collins, PhD,

Anthony P. Kontos, PhD, Sara P.D. Chrisman, MD, MPH, Alison Brooks, MD, MPH, Jonathan C. Jackson, MD, Gerald McGinty, DPT, Kenneth L. Cameron, PhD, MPH, ATC, Adam Susmarski, DO, Patrick G. O'Donnell, MHA, Stefan Duma, PhD, Steve Rowson, PhD, Christopher M. Miles, MD, Christopher T. Bullers, MD,

Brian H. Dykhuizen, MS, ATC, Laura Lintner, DO, Thomas A. Buckley, EdD, ATC,

and the CARE Consortium Investigators

Neurology ${ }^{\circledR}$ 2020;95:e2935-e2944. doi:10.1212/WNL.0000000000010672

\section{Abstract}

\section{Objective}

To examine the association between estimated age at first exposure (eAFE) to American football and clinical measures throughout recovery following concussion.

\section{Methods}

Participants were recruited across 30 colleges and universities as part of the National Collegiate Athletic Association (NCAA)-Department of Defense Concussion Assessment, Research and Education Consortium. There were 294 NCAA American football players (age $19 \pm 1$ years) evaluated 24-48 hours following concussion with valid baseline data and 327 (age $19 \pm 1$ years) evaluated at the time they were asymptomatic with valid baseline data. Participants sustained a medically diagnosed concussion between baseline testing and postconcussion assessments. Outcome measures included the number of days until asymptomatic, Immediate Post-Concussion Assessment and Cognitive Testing (ImPACT) composite scores, Balance Error Scoring System (BESS) total score, and Brief Symptom Inventory 18 (BSI-18) subscores. The eAFE was defined as participant's age at the time of assessment minus self-reported number of years playing football.

\section{Results}

In unadjusted regression models, younger eAFE was associated with lower (worse) ImPACT Visual Motor Speed $\left(R^{2}=0.031, p=0.012\right)$ at $24-48$ hours following injury and lower (better) BSI-18 Somatization subscores $\left(R^{2}=0.014, p=0.038\right)$ when the athletes were asymptomatic. The effect sizes were very small. The eAFE was not associated with the number of days until asymptomatic, other ImPACT composite scores, BESS total score, or other BSI-18 subscores.

\section{Conclusion}

Earlier eAFE to American football was not associated with longer symptom recovery, worse balance, worse cognitive performance, or greater psychological distress following concussion. In these NCAA football players, longer duration of exposure to football during childhood and adolescence appears to be unrelated to clinical recovery following concussion.

\author{
Correspondence \\ Thomas A. Buckley \\ tbuckley@udel.edu
}

\section{RELATED ARTICLE}

\section{Editorial}

Recovery after footballrelated concussion: Does age of first exposure matter?

Page 945

\footnotetext{
From the Ohio State University College of Medicine (J.B.C.), Columbus; University of Florida (Z.H., J.R.C.), Gainesville; University of Delaware (T.W.K., K.N.B., T.A.B.), Newark; Harvard Medical School (G.L.I.), Boston; Spaulding Rehabilitation Hospital and Spaulding Research Institute (G.L.I.), Charlestown; MassGeneral Hospital for Children (G.L.I.), Boston; Home Base (G.L.I.), A Red Sox Foundation and Massachusetts General Hospital Program, Boston; The Micheli Center for Sports Injury Prevention (J.R.O.), Boston Children's Hospital, Waltham, MA; Uniformed Services University of the Health Sciences (P.F.P.), Bethesda; Walter Reed National Military Medical Center (P.F.P.), Bethesda, MD; University of Michigan (S.P.B.), Ann Arbor; Indiana University School of Medicine (T.W.M.), Indianapolis; Medical College of Wisconsin (M.M.), Milwaukee; Azusa Pacific University (A.M.H.), CA; Bloomsburg University (J.B.H.), PA; California Lutheran University (L.A.K.), Thousand Oaks; Humboldt State University (J.D.O.), Arcata, CA; Indiana University (N.P.), Bloomington; Princeton University (M.P.), NJ; Temple University (T.D.L.), Philadelphia, PA; University of California (C.C.G., J.T.G.), Los Angeles; University of Chicago (H.J.B.), IL; University of Georgia (J.D.S.), Athens; University of Miami (L.A.F.), FL; University of Michigan (I.T.E.), Ann Arbor; University of North Carolina at Chapel Hill (J.P.M.); University of North Georgia (J.D.M.), Dahlonega; University of Oklahoma (S.A.), Norman; University of Pennsylvania (C.L.M.), Philadelphia; University of Pittsburgh (M.W.C., A.P.K.), PA; University of Washington (S.P.D.C.), Seattle; University of Wisconsin-Madison (A.B.); United States Air Force Academy (I.C.J., G.M.), Colorado Springs, CO; United States Military Academy (K.L.C.), West Point, NY; United States Naval Academy (A.S.), Annapolis, MD; United States Coast Guard Academy (P.G.O.), New London, CT; Virginia Tech (S.D., S.R.), Blacksburg; Wake Forest University (C.M.M., C.T.B.), Winston-Salem, NC; Wilmington College (B.H.D.), OH; Winston-Salem University (L.L.), NC.

Go to Neurology.org/N for full disclosures. Funding information and disclosures deemed relevant by the authors, if any, are provided at the end of the article.

This Null Hypothesis article is published as part of a collaborative effort between Neurology and CBMRT.
} 


\section{Glossary}

AFE $=$ age at first exposure; $\mathbf{B E S S}=$ Balance Error Scoring System $; \mathbf{B I C}=$ Bayesian information criterion; $\mathbf{B S I}=$ Brief Symptom Inventory; CARE = Concussion Assessment, Research and Education; eAFE = estimated age at first exposure; GSI = Global Severity Index; ImPACT = Immediate Post-Concussion Assessment and Cognitive Testing; LOC = loss of consciousness; NCAA = National Collegiate Athletic Association; NFL = National Football League; PTA = posttraumatic amnesia; RGA = retrograde amnesia; $\mathrm{SES}=$ socioeconomic status.

Earlier age at first exposure (AFE) to American football has been associated with worse neuropsychological test performance, ${ }^{1}$ microstructural differences in the corpus callosum measured by diffusion tensor imaging, ${ }^{2}$ and smaller volumes measured in the thalamus ${ }^{3}$ among retired National Football League (NFL) players recruited from the Diagnosing and Evaluating Traumatic Encephalopathy Using Clinical Tests (DETECT) study. In contrast, a separate study of retired NFL players found no association between earlier estimated AFE (eAFE) and neurocognitive, neurologic, or neuroradiologic outcomes. ${ }^{4} \mathrm{~A}$ recently published large-scale survey study of retired NFL players $(n=3,506)$ found that greater number of seasons playing professional football was associated with greater risk for later-in-life mental health and cognitive difficulties; however, there was no association between AFE to football and increased risk for later in life depression, anxiety, or cognitive impairment. ${ }^{5}$ Moreover, 5 large-scale cross-sectional cohort studies of current collegiate and high school American football players and other contact sport athletes found no association between eAFE and baseline preseason neurocognitive function. ${ }^{6-10}$

It has been hypothesized that exposure to football at an early age might interfere with neurodevelopmental maturation and increase vulnerability to neurologic consequences later in life. ${ }^{1,11}$ If so, it is possible that neurobiological changes from early participation in American football, if present, are sufficiently compensated for in otherwise healthy individuals, but when faced with injury (i.e., concussion), earlier eAFE may associate with longer symptom recovery, worse cognitive performance, or greater psychological distress. Cognitive reserve is a theory suggesting some individuals may have more efficient utilization of brain networks, which attempts to explain why there does not appear to be a strong and immutable relationship between degree of brain neuropathology and clinical manifestations in many older adults. ${ }^{12,13}$ This theory was originally proposed to explain individuals' resistance and resilience to the clinical manifestations of Alzheimer disease. ${ }^{14,15}$ A preliminary study suggested cognitive reserve may forestall clinical manifestations of chronic traumatic encephalopathy. ${ }^{16}$ Cognitive reserve is thought to be influenced by both genetic ${ }^{12,13}$ and lifestyle factors. ${ }^{17-19}$ Earlier eAFE to American football may gradually reduce cognitive reserve via exposure to repetitive head impacts. If so, a concussion within the context of reduced cognitive reserve could result in greater clinical manifestations (e.g., greater symptoms or worse cognitive performance).
This study examined the association between eAFE to American football and clinical measures throughout recovery following concussion. The null hypothesis for the present study is that earlier eAFE to American football is not associated with worse cognitive performance, greater psychiatric distress, or longer recovery time following concussion.

\section{Methods}

\section{Standard protocol approvals, registrations, and patient consents}

All participants provided written informed consent that was approved by their local institution and the US Army Human Research Protection Office. This study was conducted in accordance with the standards of ethics outlined in the Declaration of Helsinki.

\section{Participants}

National Collegiate Athletic Association (NCAA) American football players were recruited across 30 colleges and universities as part of the NCAA-Department of Defense Concussion Assessment, Research and Education (CARE) Consortium. A detailed description of the CARE Consortium methods is provided elsewhere. ${ }^{20}$ Inclusion criteria included male American football players who sustained a sport-related concussion and completed a multimodal concussion assessment battery at baseline, postinjury (i.e., within 6 hours), within 24-48 hours of injury, and at the time they reported being asymptomatic. For individuals who sustained multiple concussions throughout their participation in the CARE Consortium, only their first concussion was included in analyses. According to the CARE Consortium, "a concussion is defined as a change in brain function following a force to the head, which may be accompanied by temporary loss of consciousness, but is identified in awake individuals with measures of neurologic and cognitive dysfunction. Identification, assessment, and diagnosis of concussive events were completed by the research and medical staff at each site."20,21

\section{Instrumentation}

Baseline and postconcussion assessments from the Clinical Study Core were used in the analyses, ${ }^{20,22,23}$ including Immediate Post-Concussion Assessment and Cognitive Testing (ImPACT), the Balance Error Scoring System (BESS), and the Brief Symptom Inventory 18 (BSI-18). Although many participants completed the entire battery of assessments, there were individuals with missing tests/time points. Each 
assessment has been described in detail elsewhere but is described briefly below: ${ }^{20,22,23}$

\section{Immediate Post-Concussion Assessment and Cognitive Testing}

The ImPACT is the most widely used computerized neuropsychological test for concussion evaluation. ${ }^{24}$ The outcome measures are 4 composite scores, including (1) verbal memory, (2) visual memory, (3) visual motor speed, (4) reaction time, and the Post-Concussion Symptom Scale. Higher verbal memory, visual memory, and visual motor speed scores reflect better neurocognitive performance, and lower reaction time scores and symptom total scores are better.

\section{Balance Error Scoring System}

The BESS is commonly used following concussion for the assessment of acute and subacute postural control. ${ }^{25}$ The outcome measure is the number of errors recorded by the administering clinician (range for scoring is 0-60, where a lower score reflects better balance).

\section{Brief Symptom Inventory 18}

The BSI-18 is a brief symptom inventory that requires respondents to rate their level of distress over the past 7 days. The BSI-18 provides subscores on 3 dimensions (somatization, depression, and anxiety); the range of possible scores for each is $0-24$, for which lower is better. In addition, a composite score, the Global Severity Index (GSI), is calculated on a range of $0-72$, for which lower is better.

\section{Demographic and medical history}

The Demographics and Personal and Family Medical History unique case report form captures demographic data, information on current and previous sport history, concussion history, and preexisting personal and family medical history. These data were used to compute eAFE (see below). In addition, race (White or other), ethnicity (Hispanic or Latino, not Hispanic or Latino, not reported), socioeconomic status (see below), concussion history (yes/no), neurodevelopmental history (i.e., yes/no for either learning disability or attention-deficit/hyperactivity disorder), psychiatric history (yes/no), history of depression (yes/no), migraine history (yes/no), headache history (i.e., nonmigraine headaches, yes/no), setting (competition or practice/training), loss of consciousness (LOC; yes/no), posttraumatic amnesia (PTA; yes/no), retrograde amnesia (RGA; yes/no), delayed removal from play or additional head trauma (yes/no), and initial postinjury ( $<6$ hours) symptom severity were considered as potential predictors in the adjusted models (table 1$){ }^{26}$

\section{Estimated age at first exposure}

The eAFE was defined as the participant's age at the time of baseline assessment minus the number of years the participant reported playing football. The minimum eAFE for this study was 5 years because this is the youngest age for Pop Warner youth football. Participants with reported eAFE prior to age 5 were excluded. The eAFE in our study assumes that participants played football continuously from when they first began. In addition, participants who reported their athletic eligibility year, instead of their total number of years playing football, or participants who did not provide their years of sport participation were excluded.

\section{Socioeconomic status}

A participant's parental socioeconomic status (SES) was calculated using the Hollingshead Four Factor Index of Social Status. ${ }^{9,27}$ Each participant reported maternal and paternal education and occupation, which were assigned numeric values: education (0-7) and occupation (0-9). ${ }^{27}$ A score of 0 corresponded to unemployed/unknown/unreported, which may be a result of a participant being a member of a single parent household. Education and occupation scores were then multiplied by 3 and 5, respectively, and summed to obtain a composite score (range 0-66) for each parent separately and then averaged to derive a single SES score per athlete. $^{27}$ Predefined SES groups were applied based on published cutoffs: low (0-19), middle-low (20-29), middle (30-39), middle-high (40-54), and high (55-66). ${ }^{27}$

\section{Statistical analyses}

For all outcome measures (i.e., ImPACT composite scores, BESS total score, and BSI-18 subscores), we computed change scores (i.e., postinjury score - baseline score). Positive change scores reflect an increase from baseline to postinjury and negative change scores reflect a decrease from baseline to postinjury. In the context of our analyses, lower ImPACT verbal memory, visual memory, and visual motor speed composite scores are worse. Higher ImPACT reaction time composite scores, PCSS symptom severity scores, BSI-18 subscores, and BESS scores are worse. We also examined the association between eAFE to American football and the time to become asymptomatic. Being asymptomatic was determined through self-reported symptom evaluations. We ran unadjusted regression models to examine the association between eAFE to American football and clinical measures throughout recovery following concussion. The dependent variable for each analysis was the change score or the time to become asymptomatic and the independent variable was eAFE (continuous). Then we ran adjusted regression models. The best model was chosen among all possible models based on the Bayesian information criterion (BIC). Minimizing the BIC returns the best fitting model, while penalizing the complexity of the model. Potential independent variables included race, socioeconomic status, concussion history, migraine history, setting, LOC, PTA, RGA, delayed removal from play or additional head trauma, and initial postinjury symptom severity. Other terms were removed due to low frequency (table 1). After computing the best fit model, we added eAFE to the model. The gain in $R^{2}$ with eAFE represents the added value of including eAFE in the model. Effect size was interpreted by Cohen $f^{2}$ of 0.02 as a small effect, 0.15 as a medium effect, and 0.35 as a large effect. Significance was defined a priori as $p<0.05$. Although we computed 21 regression models, we did not apply a Bonferroni correction 
Table 1 Participant preinjury and injury characteristics and distributional statistics for change scores

\begin{tabular}{|c|c|c|}
\hline & $\begin{array}{l}24-48 \\
\text { hours }\end{array}$ & Asymptomatic \\
\hline Age, y & $19 \pm 1$ & $19 \pm 1$ \\
\hline eAFE, y & $10 \pm 3$ & $10 \pm 3$ \\
\hline Race: White & $\begin{array}{l}121 \\
(41.2)\end{array}$ & $137(41.9)$ \\
\hline Race: other & $\begin{array}{l}173 \\
(58.8)\end{array}$ & $190(58.1)$ \\
\hline Ethnicity: Hispanic or Latino & $14(4.8)$ & $13(4)$ \\
\hline Ethnicity: not Hispanic or Latino & $203(69)$ & $234(71.6)$ \\
\hline Ethnicity: not reported & $77(26.2)$ & $80(24.5)$ \\
\hline SES: high & $79(27.1)$ & $89(27.2)$ \\
\hline SES: mid-high & $87(29.9)$ & $101(30.9)$ \\
\hline SES: middle & $48(16.5)$ & $54(16.5)$ \\
\hline SES: mid-low & $27(9.3)$ & $32(9.8)$ \\
\hline SES: Iow & $50(17.2)$ & $48(14.7)$ \\
\hline Positive concussion history & $\begin{array}{l}138 \\
(46.9)\end{array}$ & $148(45.3)$ \\
\hline Positive ADHD & $28(9.5)$ & $36(11)$ \\
\hline Positive LD & $10(3.4)$ & $15(4.6)$ \\
\hline Positive neurodevelopmental history & $34(11.6)$ & $44(13.5)$ \\
\hline Positive psychiatric history & $5(1.7)$ & $4(1.2)$ \\
\hline Positive depression history & $3(1)$ & $3(0.9)$ \\
\hline Positive migraine history & $27(9.2)$ & $28(8.6)$ \\
\hline Positive headache history & $4(1.4)$ & $4(1.2)$ \\
\hline Setting: competition & $78(26.5)$ & $88(26.9)$ \\
\hline Setting: practice/training & $\begin{array}{l}216 \\
(73.5)\end{array}$ & $239(73.1)$ \\
\hline LOC & $18(6.1)$ & $21(6.4)$ \\
\hline PTA & $49(16.7)$ & $57(17.4)$ \\
\hline RGA & $27(9.2)$ & $30(9.2)$ \\
\hline $\begin{array}{l}\text { Delayed removal from play or } \\
\text { additional head trauma }\end{array}$ & $\begin{array}{l}120 \\
(40.8)\end{array}$ & $129(39.4)$ \\
\hline Postinjury symptom severity & $29 \pm 21$ & $28 \pm 21$ \\
\hline BESS difference & $1 \pm 8$ & $-1 \pm 7$ \\
\hline BSI-18 somatization difference & $1 \pm 3$ & $0 \pm 2$ \\
\hline BSI-18 anxiety difference & $1 \pm 2$ & $0 \pm 2$ \\
\hline BSI-18 depression difference & $1 \pm 3$ & $0 \pm 2$ \\
\hline BSI-18 GSI difference & $3 \pm 7$ & $-1 \pm 5$ \\
\hline ImPACT RT difference & $\begin{array}{l}0.04 \pm \\
0.18\end{array}$ & $-0.01 \pm 0.11$ \\
\hline ImPACT symptom severity diffe & $15 \pm 19$ & $-1 \pm 7$ \\
\hline
\end{tabular}

(e.g., $0.05 / 21=0.002$ ) to maximize our chances of refuting the null hypothesis. All analyses were conducted using JMP version 14 (SAS Institute, Cary, NC).

\section{Data availability}

CARE Consortium data are available through FITBIR (fitbir. nih.gov/).

\section{Results}

There were 294 NCAA American football players (age $19 \pm 1$ years) who were evaluated 24-48 hours following sportrelated concussion and had valid baseline data and postinjury symptom severity scores and 327 (age $=19 \pm 1$ years) who were evaluated at the time they were asymptomatic and had valid baseline data and postinjury symptom severity scores (table 1).

Results of unadjusted regression models suggested that younger eAFE was associated with lower (worse) ImPACT visual motor speed change scores $\left(R^{2}=0.031, p=0.012\right)$ at 24-48 hours and lower (better) BSI-18 somatization subscore change scores $\left(R^{2}=0.014, p=0.038\right)$ when the athletes were asymptomatic (table 2 and figures 1 and 2). eAFE was not associated with number of days until becoming asymptomatic, other ImPACT composite scores, BESS total score, or other BSI-18 subscores (table 2). Results of the adjusted models were the same as the results of the unadjusted models (table 3). Effect sizes were small (i.e., ImPACT visual motor speed composite score, $\mathrm{f}^{2}=0.036$; BSI-18 somatization subscore, $\left.f^{2}=0.014\right)$.

Measures included in the best fit models are provided in table 4. Most models were weak, accounting for less than $5 \%$ of the variance in the change scores (table 3 ). At 24-48 hours, postinjury symptom severity was the best predictor of BSI-18 somatization, BSI-18 anxiety, BSI-18 GSI, and 
Table 2 Results of the unadjusted regression models for change scores

\begin{tabular}{|c|c|c|c|c|c|c|}
\hline & \multicolumn{3}{|c|}{ 24-48 hours } & \multicolumn{3}{|c|}{ Asymptomatic } \\
\hline & $\mathbf{N}$ & $R^{2}$ & $\begin{array}{l}p \\
\text { Value }\end{array}$ & $\mathbf{N}$ & $R^{2}$ & $\begin{array}{l}p \\
\text { Value }\end{array}$ \\
\hline BESS difference & 267 & 0.000 & 0.804 & 298 & 0.006 & 0.190 \\
\hline $\begin{array}{l}\text { BSI-18 somatization } \\
\text { difference }\end{array}$ & 274 & 0.001 & 0.636 & 301 & 0.014 & 0.038 \\
\hline $\begin{array}{l}\text { BSI-18 anxiety } \\
\text { difference }\end{array}$ & 274 & 0.000 & 0.720 & 301 & 0.010 & 0.080 \\
\hline $\begin{array}{l}\text { BSI-18 depression } \\
\text { difference }\end{array}$ & 274 & 0.004 & 0.279 & 301 & 0.000 & 0.797 \\
\hline BSI-18 GSI difference & 274 & 0.001 & 0.692 & 301 & 0.010 & 0.090 \\
\hline $\begin{array}{l}\text { ImPACT verbal } \\
\text { memory difference }\end{array}$ & 204 & 0.019 & 0.051 & 235 & 0.006 & 0.223 \\
\hline $\begin{array}{l}\text { ImPACT visual } \\
\text { memory difference }\end{array}$ & 204 & 0.000 & 0.951 & 235 & 0.003 & 0.405 \\
\hline $\begin{array}{l}\text { ImPACT visual } \\
\text { motor speed } \\
\text { difference }\end{array}$ & 204 & 0.031 & 0.012 & 229 & 0.000 & 0.796 \\
\hline $\begin{array}{l}\text { ImPACT RT } \\
\text { difference }\end{array}$ & 204 & 0.000 & 0.760 & 234 & 0.004 & 0.365 \\
\hline $\begin{array}{l}\text { ImPACT symptom } \\
\text { severity difference }\end{array}$ & 198 & 0.005 & 0.304 & 223 & 0.001 & 0.694 \\
\hline $\begin{array}{l}\text { Days until } \\
\text { asymptomatic }\end{array}$ & & & & 322 & 0.000 & 0.791 \\
\hline
\end{tabular}

Abbreviations: BESS = Balance Error Scoring System; BSI = Brief Symptom Inventory; GSI = Global Severity Index; ImPACT = Immediate Post-Concussion Assessment and Cognitive Testing; RT = reaction time.

ImPACT Symptom Severity change scores $\left(R^{2}=0.222\right.$, $R^{2}=0.157, R^{2}=0.278, R^{2}=0.425$, respectively).

\section{Discussion}

This is the first study to examine whether NCAA American football players who have longer lifetime exposure to the sport have worse clinical outcome following concussion. The shortand long-term effects of repetitive neurotrauma on brain health are a fundamental concern facing the sports medicine community and there has been speculation that playing football during critical periods of neurodevelopment (i.e., before age 12) may be associated with greater later-life cognitive, behavioral, and mood dysfunction. ${ }^{2,5}$ There is a steadily growing body of literature, however, that is not supporting this theory. ${ }^{4-10,28,29}$ For example, Caccese et al. ${ }^{7}$ assessed neurocognitive performance in over 4,000 NCAA American football players and reported that earlier eAFE was not associated with worse baseline neurocognitive performance. Roberts et al. ${ }^{5}$ surveyed 3,506 former NFL players and found no association between AFE and increased risk for later-in-life anxiety, depression, or self-reported cognitive impairment. The present study examined whether potential latent differences in brain health in those with longer lifetime exposure to football might manifest in greater or prolonged symptoms, cognitive deficits, or balance problems following a concussion. Our findings suggest that younger eAFE was associated with worse ImPACT visual motor speed at 24-48 hours and better BSI-18 somatization subscore at the time athletes were asymptomatic. The effect sizes for these conflicting findings were small, and had we corrected for multiple comparisons, the effects would not have been significant. These findings do not support the theory that repetitive head trauma associated with playing football during childhood and adolescence may disrupt developmental processes and decrease cognitive reserve, resulting in worse outcomes following concussion during the collegiate years.

The extent to which preinjury and injury severity characteristics are associated with clinical recovery from concussion is not well understood, and the literature is mixed. ${ }^{26}$ Based on small measure estimates for preinjury and injury severity characteristics, our findings suggest these factors have marginal practical relevance. Most research to date supports an association between greater acute/subacute symptoms and clinical recovery from concussion. ${ }^{26}$ Our findings suggest that postinjury $(<6$ hours) symptom severity was a strong predictor of change scores (i.e., BSI- 18 somatization, $R^{2}=0.222$; anxiety, $R^{2}=$ 0.157 ; GSI, $R^{2}=0.278$; ImPACT symptom severity, $R^{2}=$ 0.425 ) at $24-48$ hours, but not at the time the athletes were asymptomatic. Greater acute symptom severity (i.e., symptom severity reported $<6$ hours following sport-related concussion) may be associated with worse clinical concussion outcomes 24-48 hours following sport-related concussion.

Figure 1 Association between estimated age at first exposure (eAFE) and Immediate Post-Concussion Assessment and Cognitive Testing (ImPACT) visual motor speed change score (i.e., 24-48 hours after injury - baseline) with linear fit in red

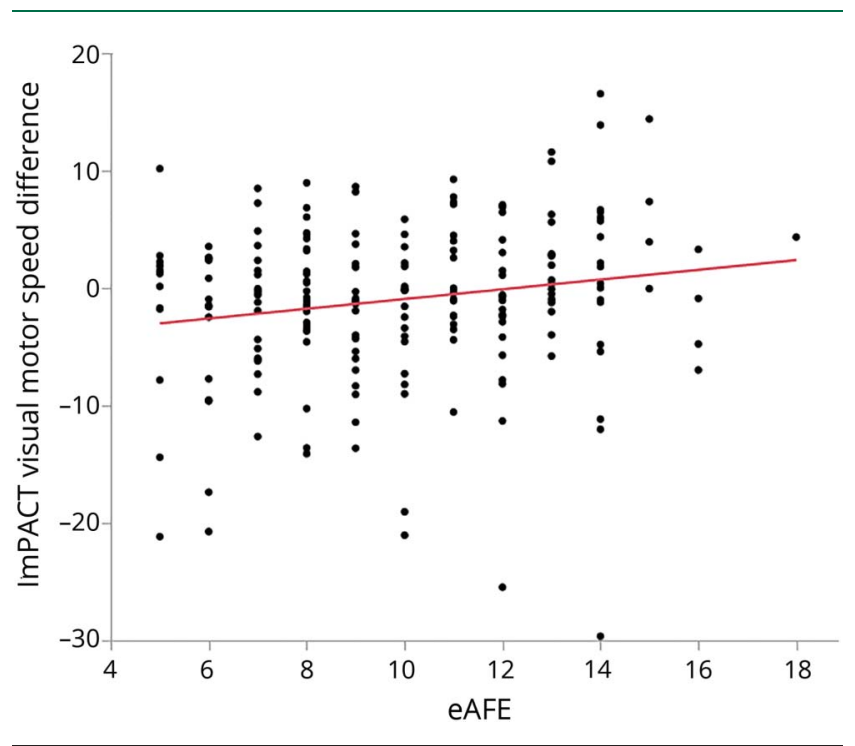


Figure 2 Association between estimated age at first exposure (eAFE) and Brief Symptom Inventory (BSI-18) somatization change score (i.e., asymptomatic baseline) with linear fit in red

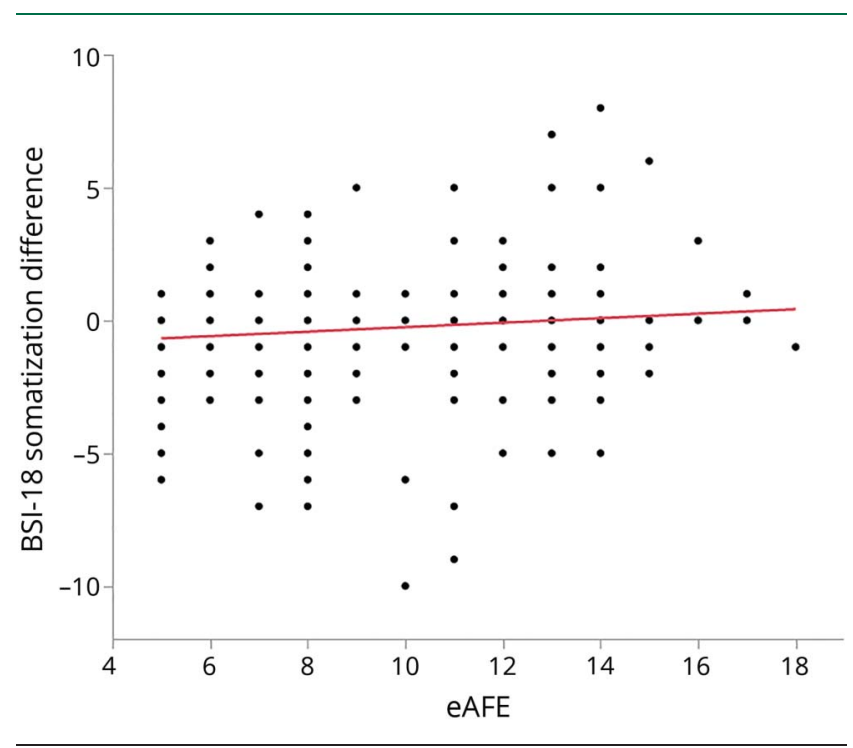

Our findings should be interpreted in the context of this study's limitations. First, like previous work, the eAFE was based on athletes' self-reporting and assumed that athletes played continuously from when they first began. Specifically, student athletes were asked to report the number of years of participation in American football. However, until we can prospectively examine the effects of a lifetime of exposure to repetitive blows to the head on clinical outcomes, these selfreported data appear to be our best option and are essential to research. ${ }^{30}$ Second, our cohort was limited to American tackle football, but concussions are common among other contact and collision sports (e.g., ice hockey, soccer, and lacrosse) ) $^{31,32}$ and the current findings may not extend to those populations, but should be further investigated. Finally, we did not account for exposure to other contact sports or player position because this may change over time and many individuals play multiple positions, especially at earlier ages; however, these may be important unmeasured variables and should be investigated further.

Longer exposure to playing American tackle football during childhood and adolescence was not associated with worse clinical outcomes following concussion in collegiate student athletes and earlier eAFE was not associated with longer concussion recovery. This study adds to a body of research with current collegiate athletes ${ }^{6-10}$ and former professional athletes ${ }^{4,5,28,29}$ showing no association between more years of playing football and worse cognitive or psychological health.

\section{Acknowledgment}

The authors thank Barry Bodt, PhD, College of Health Sciences, University of Delaware, for consulting with statistical design and analysis.

Table 3 Results of the adjusted models for change scores

\begin{tabular}{|c|c|c|c|c|c|c|c|c|}
\hline & \multicolumn{4}{|c|}{ 24-48 hours } & \multicolumn{4}{|c|}{ Asymptomatic } \\
\hline & $\mathbf{N}$ & $\begin{array}{l}\text { Best fit, } \\
R^{2}\end{array}$ & $\begin{array}{l}\text { With eAFE, } \\
R^{2}\end{array}$ & $\begin{array}{l}\text { eAFE effect, } p \\
\text { Value }\end{array}$ & $\mathbf{N}$ & $\begin{array}{l}\text { Best fit, }{ }^{a} \\
R^{2}\end{array}$ & $\begin{array}{l}\text { With eAFE, } \\
R^{2}\end{array}$ & $\begin{array}{l}\text { eAFE effect, } p \\
\text { Value }\end{array}$ \\
\hline BESS difference & 267 & 0.027 & 0.027 & 0.896 & 294 & 0.038 & 0.043 & 0.194 \\
\hline BSI-18 somatization difference & 274 & 0.254 & 0.256 & 0.518 & 301 & 0.010 & 0.024 & 0.040 \\
\hline BSI-18 anxiety difference & 270 & 0.161 & 0.161 & 0.951 & 298 & 0.021 & 0.032 & 0.064 \\
\hline BSI-18 depression difference & 271 & 0.024 & 0.027 & 0.318 & 300 & 0.015 & 0.015 & 0.685 \\
\hline BSI-18 GSI difference & 267 & 0.342 & 0.343 & 0.751 & 298 & 0.021 & 0.032 & 0.070 \\
\hline $\begin{array}{l}\text { ImPACT verbal memory } \\
\text { difference }\end{array}$ & 204 & 0.041 & 0.056 & 0.081 & 234 & 0.028 & 0.035 & 0.211 \\
\hline $\begin{array}{l}\text { ImPACT visual memory } \\
\text { difference }\end{array}$ & 202 & 0.012 & 0.013 & 0.596 & 226 & 0.042 & 0.045 & 0.362 \\
\hline $\begin{array}{l}\text { ImPACT visual motor speed } \\
\text { difference }\end{array}$ & 202 & 0.128 & 0.151 & 0.023 & 223 & 0.013 & 0.014 & 0.803 \\
\hline ImPACT RT difference & 204 & 0.068 & 0.068 & 0.999 & 232 & 0.011 & 0.015 & 0.344 \\
\hline $\begin{array}{l}\text { ImPACT symptom severity } \\
\text { difference }\end{array}$ & 198 & 0.430 & 0.430 & 0.807 & 222 & 0.016 & 0.017 & 0.650 \\
\hline Days until asymptomatic & & & & & 317 & 0.015 & 0.015 & 0.985 \\
\hline
\end{tabular}

Abbreviations: BESS = Balance Error Scoring System; BSI = Brief Symptom Inventory; eAFE = estimated age at first exposure; GSI = Global Severity Index; ImPACT = Immediate Post-Concussion Assessment and Cognitive Testing; $\mathrm{RT}=$ reaction time.

${ }^{a} R^{2}$ of the model selected from all possible models to best represent the data.

${ }^{\mathrm{b}} R^{2}$ of the model with eAFE added. 
Table 4 Measure estimates, standard errors (SEs), and test results for measures input into best fit models

\begin{tabular}{|c|c|c|c|c|c|}
\hline Outcome & Measure & Estimate & SE & $t$ & $p$ Value \\
\hline \multicolumn{6}{|l|}{ 24-48 hours } \\
\hline BESS difference & Postinjury symptom severity & 0.063 & 0.023 & 2.69 & 0.008 \\
\hline \multirow[t]{2}{*}{ BSI-18 somatization difference } & Postinjury symptom severity & 0.069 & 0.008 & 9.15 & $<0.001$ \\
\hline & Race: other & 0.560 & 0.164 & 3.40 & 0.001 \\
\hline \multirow[t]{2}{*}{ BSI-18 anxiety difference } & Postinjury symptom severity & 0.042 & 0.006 & 7.02 & $<0.001$ \\
\hline & Positive neurodevelopmental history & -0.229 & 0.203 & -1.13 & 0.260 \\
\hline BSI-18 depression difference & LOC & 1.001 & 0.390 & 2.56 & 0.011 \\
\hline \multirow[t]{5}{*}{ BSI-18 GSI difference } & Postinjury symptom severity & 0.185 & 0.017 & 10.82 & $<0.001$ \\
\hline & Race: other & 0.975 & 0.370 & 2.64 & 0.009 \\
\hline & Positive concussion history & -0.433 & 0.366 & -1.18 & 0.238 \\
\hline & SES: middle, middle-high, high, middle-low, and low & -1.044 & 0.368 & -2.84 & 0.005 \\
\hline & LOC & 1.850 & 0.750 & 2.47 & 0.014 \\
\hline ImPACT verbal memory difference & Postinjury symptom severity & -0.129 & 0.044 & -2.94 & 0.004 \\
\hline ImPACT visual memory difference & SES: all-low & -1.856 & 1.213 & -1.53 & 0.128 \\
\hline \multirow[t]{2}{*}{ ImPACT visual motor speed difference } & Postinjury symptom severity & -0.104 & 0.021 & -4.97 & $<0.001$ \\
\hline & Positive neurodevelopmental history & -1.965 & 0.766 & -2.56 & 0.011 \\
\hline ImPACT RT difference & Postinjury symptom severity & 0.002 & 0.001 & 3.84 & $<0.001$ \\
\hline \multirow[t]{2}{*}{ ImPACT symptom severity difference } & Postinjury symptom severity & 0.563 & 0.046 & 12.13 & $<0.001$ \\
\hline & SES: high-middle-low & 2.205 & 1.763 & 1.25 & 0.212 \\
\hline \multirow[t]{3}{*}{ Days until asymptomatic } & Postinjury symptom severity & -0.038 & 0.030 & -1.27 & 0.206 \\
\hline & Positive migraine history & -0.630 & 1.125 & -0.56 & 0.576 \\
\hline & SES: all-low & -1.314 & 0.879 & -1.50 & 0.136 \\
\hline \multicolumn{6}{|l|}{ Asymptomatic } \\
\hline \multirow[t]{2}{*}{ BESS difference } & LOC & -2.075 & 0.861 & -2.41 & 0.017 \\
\hline & PTA & 1.617 & 0.568 & 2.85 & 0.005 \\
\hline BSI-18 somatization difference & Race: other & 0.213 & 0.122 & 1.75 & 0.081 \\
\hline BSI-18 anxiety difference & PTA & 0.305 & 0.121 & 2.52 & 0.012 \\
\hline BSI-18 depression difference & SES: high, middle-low, middle-high, middle, and low & -0.242 & 0.115 & -2.10 & 0.036 \\
\hline BSI-18 GSI difference & PTA & 0.855 & 0.339 & 2.52 & 0.012 \\
\hline ImPACT verbal memory difference & Positive migraine history & -3.124 & 1.209 & -2.58 & 0.010 \\
\hline \multirow[t]{2}{*}{ ImPACT visual memory difference } & Positive neurodevelopmental history & 2.749 & 1.159 & 2.37 & 0.019 \\
\hline & SES: high, middle-high, middle-low, middle, and low & -1.727 & 0.801 & -2.16 & 0.032 \\
\hline ImPACT visual motor speed difference & Positive neurodevelopmental history & -0.837 & 0.486 & -1.72 & 0.087 \\
\hline ImPACT RT difference & SES: middle-high, low-high, middle, and middle-low & -0.011 & 0.007 & -1.61 & 0.109 \\
\hline ImPACT symptom severity difference & Positive migraine history & -1.226 & 0.654 & -1.87 & 0.062 \\
\hline
\end{tabular}

Abbreviations: BESS = Balance Error Scoring System; BSI = Brief Symptom Inventory; GSI = Global Severity Index; ImPACT = Immediate Post-Concussion Assessment and Cognitive Testing; LOC = loss of consciousness; PTA = posttraumatic amnesia; RT = reaction time; SES = socioeconomic status. 


\section{Study funding}

This publication was made possible, in part, with support from the Grand Alliance CARE Consortium, funded by the NCAA and the Department of Defense. The USAMRAA, Ford Detrick, MD, is the awarding and administering acquisition office. This work was supported by the Office of the Assistant Secretary of Defense for Health Affairs through the Psychological Health and Traumatic Brain Injury Program under award W81XWH-14-2-0151. Opinions, interpretations, conclusions, and recommendations are those of the authors and are not necessarily endorsed by the Department of Defense (DHP funds).

\section{Disclosure}

J.B. Caccese and Z. Houck report no disclosures. T.W. Kaminski and J.R. Clugston report support from the Grand Alliance CARE Consortium. G.L. Iverson serves as a scientific advisor for BioDirection, Inc., Sway Operations, LLC, and Highmark, Inc.; has a consulting practice in forensic neuropsychology, including expert testimony; has received research funding from several test publishing companies, including ImPACT Applications, Inc., CNS Vital Signs, and Psychological Assessment Resources (PAR, Inc.); has received research funding as a principal investigator from the National Football League and salary support as a collaborator from the Harvard Integrated Program to Protect and Improve the Health of National Football League Players Association Members; and acknowledges unrestricted philanthropic support from ImPACT Applications, Inc., the Heinz Family Foundation, the Boston Bolts, the Mooney-Reed Charitable Foundation, and the Spaulding Research Institute. K. Bryk and J.R. Oldham report no disclosures. P.F. Pasquina, S.P. Broglio, T.W. McAllister, M. McCrea, A.M. Hoy, J.B. Hazzard, L.A. Kelly, J.D. Ortega, and N. Port report support from the Grand Alliance CARE Consortium. M. Putukian reports support from the Grand Alliance CARE Consortium; chief medical officer, Major League Soccer; committee member, NFL Head, Neck \& Spine Committee; and grant support from Ivy League-Big Ten Concussion Summit. T.D. Langford reports support from the Grand Alliance CARE Consortium. C.C. Giza reports support from the Grand Alliance CARE Consortium, NCAA, US Department of Defense, UCLA Steve Tisch BrainSPORT program, NIH National Institute of Neurological Disorders and Stroke (R01 NS110757 2019-2024), UCLA Brain Injury Research Center, Easton Clinic for Brain Health, National Institute of Neurological Disorders and Stroke Neural Analytics SBIR grant (NS092209 2016-2020), and Richie's Fund (2018-2019); clinical consultant: NBA, NFL-Neurological Care Program, NHLPA; advisory board: Highmark Interactive (2018-2020), Novartis Pharmaceutical (2019), MLS, NBA, USSF; medicolegal: 1 or 2 cases annually; stock shareholder: Highmark Interactive stock options (2018); and book royalties from Blackwell/Wiley Publishing for Prioritized Neurologic Differential Diagnosis. J.T. Goldman, H.J. Benjamin, J.D. Schmidt, L.A. Feigenbaum, J.T. Eckner, J.P. Mihalik, J.D.
Miles, S. Anderson, C.L. Master, M. Collins, A.P. Kontos, S.P. Chrisman, A. Brooks, J.C. Jackson, G. McGinty, K.L. Cameron, A. Susmarski, P.G. O’Donnell, S. Duma, S. Rowson, C.M. Miles, C.T. Bullers, B.H. Dykhuizen, and L. Lintner report support from the Grand Alliance CARE Consortium. T.A. Buckley reports support from the Grand Alliance CARE Consortium and support from the NIH/National Institute of Neurological Disorders and Stroke (R03NS104371). Go to Neurology.org/N for full disclosures.

\section{Publication history}

Received by Neurology June 5, 2019. Accepted in final form July 30, 2020.

Appendix Authors

\begin{tabular}{|c|c|c|}
\hline Name & Location & Contribution \\
\hline $\begin{array}{l}\text { Jaclyn B. } \\
\text { Caccese, PhD }\end{array}$ & $\begin{array}{l}\text { The Ohio State University } \\
\text { College of Medicine, } \\
\text { Columbus }\end{array}$ & $\begin{array}{l}\text { Designed and } \\
\text { conceptualized study, } \\
\text { analyzed the data, } \\
\text { drafted the manuscript } \\
\text { for intellectual } \\
\text { content }\end{array}$ \\
\hline $\begin{array}{l}\text { Zac Houck, } \\
\text { MS }\end{array}$ & $\begin{array}{l}\text { University of Florida, } \\
\text { Gainesville }\end{array}$ & $\begin{array}{l}\text { Designed and } \\
\text { conceptualized study, } \\
\text { revised the manuscript } \\
\text { for intellectual } \\
\text { content }\end{array}$ \\
\hline $\begin{array}{l}\text { Thomas W. } \\
\text { Kaminski, } \\
\text { PhD, ATC }\end{array}$ & $\begin{array}{l}\text { University of Delaware, } \\
\text { Newark }\end{array}$ & $\begin{array}{l}\text { Designed and } \\
\text { conceptualized study, } \\
\text { revised the manuscript } \\
\text { for intellectual } \\
\text { content }\end{array}$ \\
\hline $\begin{array}{l}\text { James R. } \\
\text { Clugston, } \\
\text { MD, MS, } \\
\text { CAQSM }\end{array}$ & $\begin{array}{l}\text { University of Florida, } \\
\text { Gainesville }\end{array}$ & $\begin{array}{l}\text { Designed and } \\
\text { conceptualized study, } \\
\text { revised the manuscript for } \\
\text { intellectual content }\end{array}$ \\
\hline $\begin{array}{l}\text { Grant L. } \\
\text { Iverson, PhD }\end{array}$ & $\begin{array}{l}\text { Harvard Medical School, } \\
\text { Boston; Spaulding } \\
\text { Rehabilitation Hospital, } \\
\text { Charlestown; Spaulding } \\
\text { Research Institute, } \\
\text { Charlestown; MassGeneral } \\
\text { Hospital for Children, } \\
\text { Boston; Home Base, A Red } \\
\text { Sox Foundation and } \\
\text { Massachusetts General } \\
\text { Hospital Program, Boston }\end{array}$ & $\begin{array}{l}\text { Designed and } \\
\text { conceptualized study, } \\
\text { revised the manuscript for } \\
\text { intellectual content }\end{array}$ \\
\hline $\begin{array}{l}\text { Kelsey N. } \\
\text { Bryk, MS }\end{array}$ & $\begin{array}{l}\text { University of Delaware, } \\
\text { Newark }\end{array}$ & $\begin{array}{l}\text { Major role in the } \\
\text { acquisition of data, revised } \\
\text { the manuscript for } \\
\text { intellectual content }\end{array}$ \\
\hline $\begin{array}{l}\text { Jessie R. } \\
\text { Oldham, PhD }\end{array}$ & $\begin{array}{l}\text { Boston Children's } \\
\text { Hospital, The Micheli } \\
\text { Center for Sports Injury } \\
\text { Prevention, Waltham, MA }\end{array}$ & $\begin{array}{l}\text { Major role in the } \\
\text { acquisition of data, revised } \\
\text { the manuscript for } \\
\text { intellectual content }\end{array}$ \\
\hline $\begin{array}{l}\text { Paul F. } \\
\text { Pasquina, } \\
\text { MD }\end{array}$ & $\begin{array}{l}\text { Uniformed Services } \\
\text { University of the Health } \\
\text { Sciences; Walter Reed } \\
\text { National Military Medical } \\
\text { Center, Bethesda, MD }\end{array}$ & $\begin{array}{l}\text { Designed and } \\
\text { conceptualized study, } \\
\text { revised the manuscript for } \\
\text { intellectual content }\end{array}$ \\
\hline $\begin{array}{l}\text { Steven P. } \\
\text { Broglio, PhD, } \\
\text { ATC }\end{array}$ & $\begin{array}{l}\text { Michigan Concussion } \\
\text { Center, University of } \\
\text { Michigan, Ann Arbor }\end{array}$ & $\begin{array}{l}\text { Designed and } \\
\text { conceptualized study, } \\
\text { revised the manuscript for } \\
\text { intellectual content }\end{array}$ \\
\hline
\end{tabular}


Appendix (continued)

\begin{tabular}{|c|c|c|}
\hline Name & Location & Contribution \\
\hline $\begin{array}{l}\text { Thomas W. } \\
\text { McAllister, } \\
\text { MD }\end{array}$ & $\begin{array}{l}\text { Indiana University School } \\
\text { of Medicine, Indianapolis }\end{array}$ & $\begin{array}{l}\text { Designed and } \\
\text { conceptualized study, } \\
\text { revised the manuscript for } \\
\text { intellectual content }\end{array}$ \\
\hline $\begin{array}{l}\text { Michael } \\
\text { McCrea, PhD, } \\
\text { ABPP }\end{array}$ & $\begin{array}{l}\text { Medical College of } \\
\text { Wisconsin, Milwaukee }\end{array}$ & $\begin{array}{l}\text { Designed and } \\
\text { conceptualized study, } \\
\text { revised the manuscript for } \\
\text { intellectual content }\end{array}$ \\
\hline $\begin{array}{l}\text { April Marie } \\
\text { (Reed) Hoy, } \\
\text { MS, ATC }\end{array}$ & $\begin{array}{l}\text { Azusa Pacific University, } \\
\text { CA }\end{array}$ & $\begin{array}{l}\text { Major role in the } \\
\text { acquisition of data, revised } \\
\text { the manuscript for } \\
\text { intellectual content }\end{array}$ \\
\hline $\begin{array}{l}\text { Joseph B. } \\
\text { Hazzard Jr, } \\
\text { EdD, ATC }\end{array}$ & Bloomsburg University, PA & $\begin{array}{l}\text { Major role in the } \\
\text { acquisition of data, revised } \\
\text { the manuscript for } \\
\text { intellectual content }\end{array}$ \\
\hline $\begin{array}{l}\text { Louise A. } \\
\text { Kelly, PhD }\end{array}$ & $\begin{array}{l}\text { California Lutheran } \\
\text { University, Thousand Oaks }\end{array}$ & $\begin{array}{l}\text { Major role in the } \\
\text { acquisition of data, revised } \\
\text { the manuscript for } \\
\text { intellectual content }\end{array}$ \\
\hline $\begin{array}{l}\text { Justus D. } \\
\text { Ortega, PhD }\end{array}$ & $\begin{array}{l}\text { Humboldt State } \\
\text { University, Arcata, CA }\end{array}$ & $\begin{array}{l}\text { Major role in the } \\
\text { acquisition of data, revised } \\
\text { the manuscript for } \\
\text { intellectual content }\end{array}$ \\
\hline $\begin{array}{l}\text { Nicholas } \\
\text { Port, PhD }\end{array}$ & $\begin{array}{l}\text { Indiana University, } \\
\text { Bloomington }\end{array}$ & $\begin{array}{l}\text { Major role in the } \\
\text { acquisition of data, revised } \\
\text { the manuscript for } \\
\text { intellectual content }\end{array}$ \\
\hline $\begin{array}{l}\text { Margot } \\
\text { Putukian, } \\
\text { MD }\end{array}$ & Princeton University, NJ & $\begin{array}{l}\text { Major role in the } \\
\text { acquisition of data, revised } \\
\text { the manuscript for } \\
\text { intellectual content }\end{array}$ \\
\hline $\begin{array}{l}\text { T. Dianne } \\
\text { Langford, } \\
\text { PhD }\end{array}$ & $\begin{array}{l}\text { Temple University, } \\
\text { Philadelphia, PA }\end{array}$ & $\begin{array}{l}\text { Major role in the } \\
\text { acquisition of data, revised } \\
\text { the manuscript for } \\
\text { intellectual content }\end{array}$ \\
\hline $\begin{array}{l}\text { Christopher } \\
\text { C. Giza, MD }\end{array}$ & $\begin{array}{l}\text { University of California, } \\
\text { Los Angeles }\end{array}$ & $\begin{array}{l}\text { Major role in the } \\
\text { acquisition of data, revised } \\
\text { the manuscript for } \\
\text { intellectual content }\end{array}$ \\
\hline $\begin{array}{l}\text { Joshua T. } \\
\text { Goldman, } \\
\text { MD, MBA }\end{array}$ & $\begin{array}{l}\text { University of California, } \\
\text { Los Angeles }\end{array}$ & $\begin{array}{l}\text { Major role in the } \\
\text { acquisition of data, revised } \\
\text { the manuscript for } \\
\text { intellectual content }\end{array}$ \\
\hline $\begin{array}{l}\text { Holly J. } \\
\text { Benjamin, } \\
\text { MD }\end{array}$ & University of Chicago, IL & $\begin{array}{l}\text { Major role in the } \\
\text { acquisition of data, revised } \\
\text { the manuscript for } \\
\text { intellectual content }\end{array}$ \\
\hline $\begin{array}{l}\text { Julianne D. } \\
\text { Schmidt, } \\
\text { PhD, ATC }\end{array}$ & $\begin{array}{l}\text { University of Georgia, } \\
\text { Athens }\end{array}$ & $\begin{array}{l}\text { Major role in the } \\
\text { acquisition of data, revised } \\
\text { the manuscript for } \\
\text { intellectual content }\end{array}$ \\
\hline $\begin{array}{l}\text { Luis A. } \\
\text { Feigenbaum, } \\
\text { DPT, ATC }\end{array}$ & University of Miami, FL & $\begin{array}{l}\text { Major role in the } \\
\text { acquisition of data, revised } \\
\text { the manuscript for } \\
\text { intellectual content }\end{array}$ \\
\hline $\begin{array}{l}\text { James T. } \\
\text { Eckner, MD, } \\
\text { MS }\end{array}$ & $\begin{array}{l}\text { University of Michigan, } \\
\text { Ann Arbor }\end{array}$ & $\begin{array}{l}\text { Major role in the } \\
\text { acquisition of data, revised } \\
\text { the manuscript for } \\
\text { intellectual content }\end{array}$ \\
\hline
\end{tabular}

Appendix (continued)

\begin{tabular}{lll}
\hline Name & Location & Contribution \\
\hline $\begin{array}{l}\text { Jason P. } \\
\text { Mihalik, PhD, }\end{array}$ & $\begin{array}{l}\text { University of North } \\
\text { CAT(C), ATC }\end{array}$ & $\begin{array}{l}\text { Major role in the } \\
\text { acquisition of data, revised } \\
\text { the manuscript for } \\
\text { intellectual content }\end{array}$
\end{tabular}

\begin{tabular}{lll}
\hline Jessica & University of North & Major role in the \\
Dysart Miles, & Georgia, Dahlonega & $\begin{array}{l}\text { acquisition of data, revised } \\
\text { the manuscript for }\end{array}$ \\
PhD, ATC & & intellectual content
\end{tabular}

\begin{tabular}{lll}
\hline $\begin{array}{l}\text { Scott } \\
\text { Anderson, } \\
\text { ATC }\end{array}$ & $\begin{array}{l}\text { University of Oklahoma, } \\
\text { Norman }\end{array}$ & $\begin{array}{l}\text { Major role in the } \\
\text { acquisition of data, revised } \\
\text { the manuscript for } \\
\text { intellectual content }\end{array}$ \\
\hline $\begin{array}{l}\text { Christina L. } \\
\text { Master, MD }\end{array}$ & $\begin{array}{l}\text { University of } \\
\text { Pennsylvania, } \\
\text { Philadelphia }\end{array}$ & $\begin{array}{l}\text { Major role in the } \\
\text { acquisition of data, revised } \\
\text { the manuscript for } \\
\text { intellectual content }\end{array}$ \\
\hline $\begin{array}{l}\text { Micky W. } \\
\text { Collins, PhD }\end{array}$ & $\begin{array}{l}\text { University of Pittsburgh } \\
\text { Medical Center, PA }\end{array}$ & $\begin{array}{l}\text { Major role in the } \\
\text { acquisition of data, revised } \\
\text { the manuscript for } \\
\text { intellectual content }\end{array}$ \\
\hline
\end{tabular}

Anthony P. University of Pittsburgh Major role in the

Kontos, PhD Medical Center, PA acquisition of data, revised the manuscript for intellectual content

\begin{tabular}{lll}
\hline Sara P. D. & University of Washington, & Major role in the \\
Chrisman, & Seattle & $\begin{array}{l}\text { acquisition of data, revised } \\
\text { the manuscript for } \\
\text { intellectual content }\end{array}$ \\
MD, MPH & & intent
\end{tabular}

\begin{tabular}{lll}
\hline Alison & University of & Major role in the \\
Brooks, MD, & Wisconsin-Madison & $\begin{array}{l}\text { acquisition of data, revised } \\
\text { the manuscript for } \\
\text { MPH }\end{array}$ \\
& & intellectual content
\end{tabular}

Jonathan C. United States Air Force Major role in the

Jackson, MD Academy, Colorado acquisition of data, revised Springs, CO the manuscript for intellectual content

\begin{tabular}{|c|c|c|}
\hline $\begin{array}{l}\text { Gerald } \\
\text { McGinty, DPT }\end{array}$ & $\begin{array}{l}\text { United States Air Force } \\
\text { Academy, Colorado } \\
\text { Springs, CO }\end{array}$ & $\begin{array}{l}\text { Major role in the } \\
\text { acquisition of data, revised } \\
\text { the manuscript for } \\
\text { intellectual content }\end{array}$ \\
\hline $\begin{array}{l}\text { Kenneth L. } \\
\text { Cameron, } \\
\text { PhD, MPH, } \\
\text { ATC }\end{array}$ & $\begin{array}{l}\text { United States Military } \\
\text { Academy, West Point, NY }\end{array}$ & $\begin{array}{l}\text { Major role in the } \\
\text { acquisition of data, revised } \\
\text { the manuscript for } \\
\text { intellectual content }\end{array}$ \\
\hline $\begin{array}{l}\text { Adam } \\
\text { Susmarski, } \\
\text { DO }\end{array}$ & $\begin{array}{l}\text { United States Naval } \\
\text { Academy, Annapolis, MD }\end{array}$ & $\begin{array}{l}\text { Major role in the } \\
\text { acquisition of data, revised } \\
\text { the manuscript for } \\
\text { intellectual content }\end{array}$ \\
\hline $\begin{array}{l}\text { Patrick G. } \\
\text { O'Donnell, } \\
\text { MHA }\end{array}$ & $\begin{array}{l}\text { United States Coast Guard } \\
\text { Academy, New London, CT }\end{array}$ & $\begin{array}{l}\text { Major role in the } \\
\text { acquisition of data, revised } \\
\text { the manuscript for } \\
\text { intellectual content }\end{array}$ \\
\hline $\begin{array}{l}\text { Stefan Duma, } \\
\text { PhD }\end{array}$ & Virginia Tech, Blacksburg & $\begin{array}{l}\text { Major role in the } \\
\text { acquisition of data, revised } \\
\text { the manuscript for } \\
\text { intellectual content }\end{array}$ \\
\hline $\begin{array}{l}\text { Steve } \\
\text { Rowson, PhD }\end{array}$ & Virginia Tech, Blacksburg & $\begin{array}{l}\text { Major role in the } \\
\text { acquisition of data, revised } \\
\text { the manuscript for } \\
\text { intellectual content }\end{array}$ \\
\hline
\end{tabular}


Appendix (continued)

\begin{tabular}{|c|c|c|}
\hline Name & Location & Contribution \\
\hline $\begin{array}{l}\text { Christopher } \\
\text { M. Miles, MD }\end{array}$ & $\begin{array}{l}\text { Wake Forest University, } \\
\text { Winston-Salem, NC }\end{array}$ & $\begin{array}{l}\text { Major role in the } \\
\text { acquisition of data, revised } \\
\text { the manuscript for } \\
\text { intellectual content }\end{array}$ \\
\hline $\begin{array}{l}\text { Christopher } \\
\text { T. Bullers, MD }\end{array}$ & $\begin{array}{l}\text { Wake Forest University, } \\
\text { Winston-Salem, NC }\end{array}$ & $\begin{array}{l}\text { Major role in the } \\
\text { acquisition of data, revised } \\
\text { the manuscript for } \\
\text { intellectual content }\end{array}$ \\
\hline $\begin{array}{l}\text { Brian H. } \\
\text { Dykhuizen, } \\
\text { MS, ATC }\end{array}$ & Wilmington College, $\mathrm{OH}$ & $\begin{array}{l}\text { Major role in the } \\
\text { acquisition of data, revised } \\
\text { the manuscript for } \\
\text { intellectual content }\end{array}$ \\
\hline $\begin{array}{l}\text { Laura } \\
\text { Lintner DO }\end{array}$ & $\begin{array}{l}\text { Winston-Salem University, } \\
\text { NC }\end{array}$ & $\begin{array}{l}\text { Major role in the } \\
\text { acquisition of data, revised } \\
\text { the manuscript for } \\
\text { intellectual content }\end{array}$ \\
\hline $\begin{array}{l}\text { Thomas A. } \\
\text { Buckley, EdD, } \\
\text { ATC }\end{array}$ & $\begin{array}{l}\text { University of Delaware, } \\
\text { Newark }\end{array}$ & $\begin{array}{l}\text { Designed and } \\
\text { conceptualized study, } \\
\text { revised the manuscript for } \\
\text { intellectual content }\end{array}$ \\
\hline
\end{tabular}

\section{References}

1. Stamm JM, Bourlas AP, Baugh CM, et al. Age of first exposure to football and later-life cognitive impairment in former NFL players. Neurology 2015;84:1114-1120.

2. Stamm JM, Koerte IK, Muehlmann M, et al. Age at first exposure to football is associated with altered corpus callosum white matter microstructure in former professional football players. J Neurotrauma 2015;32:1768-1776.

3. Schultz V, Stern RA, Tripodis Y, et al. Age at first exposure to repetitive head impacts is associated with smaller thalamic volumes in former professional American football players. J Neurotrauma 2018;35:278-285.

4. Solomon GS, Kuhn AW, Zuckerman SL, et al. Participation in pre-high school football and neurological, neuroradiological, and neuropsychological findings in later life: a study of 45 retired national football league players. Am J Sports Med 2016;44: 1106-1115.

5. Roberts AL, Pascual-Leone A, Speizer FE, et al. Exposure to American football and neuropsychiatric health in former National Football League players: findings from the Football Players Health Study. Am J Sports Med 2019;47:2871-2880.

6. Caccese JB, Iverson GL, Cameron K, et al. Estimated age of first exposure to contact sports is not associated with greater symptoms or worse cognitive functioning in US service academy athletes. J Neurotrauma 2020;37:334-339.

7. Caccese JB, DeWolf RM, Kaminski TW, et al. Estimated age of first exposure to American football and neurocognitive performance amongst NCAA male studentathletes: a cohort study. Sports Med 2019;49:477-487.

8. Brett BL, Huber DL, Wild A, et al. Age of first exposure to American football and behavioral, cognitive, psychological, and physical outcomes in high school and collegiate football players. Sports Health 2019;11:332-342.

9. Houck Z, Asken B, Clugston J, et al. Socioeconomic status and race outperform concussion history and sport participation in predicting collegiate athlete baseline neurocognitive scores. J Int Neuropsychol Soc 2018;24:1-10.
10. Houck ZM, Asken BM, Bauer RM, et al. Academic aptitude mediates the relationship between socioeconomic status and race in predicting ImPACT scores in college athletes. Clin Neuropsychol 2020;34:561-579.

11. Alosco ML, Stern RA. Youth exposure to repetitive head impacts from tackle football and long-term neurologic outcomes: a review of the literature, knowledge gaps and future directions, and societal and clinical implications. Semin Pediatr Neurol 2019; 30:107-116.

12. Stern Y. Cognitive reserve. Neuropsychologia 2009;47:2015-2028.

13. Stern Y. What is cognitive reserve? Theory and research application of the reserve concept. J Int Neuropsychol Soc 2002;8:448-460.

14. Stern Y. Cognitive reserve and Alzheimer disease. Alzheimer Dis Assoc Disord 2006; 20:S74

15. Stern Y. Cognitive reserve in ageing and Alzheimer's disease. Lancet Neurol 2012;11: 1006-1012.

16. Alosco ML, Mez J, Kowall NW, et al. Cognitive reserve as a modifier of clinical expression in chronic traumatic encephalopathy: a preliminary examination. J Neuropsychiatry Clin Neurosci 2017;29:6-12.

17. Scarmeas N, Stern Y. Cognitive reserve and lifestyle. J Clin Exp Neuropsychol 2003; 25:625-633.

18. Broe GA, Creasey H, Jorm AF, et al. Health habits and risk of cognitive impairment and dementia in old age: a prospective study on the effects of exercise, smoking and alcohol consumption. Aust NZ J Public Health 1998;22:621-623.

19. Van Uffelen JG, Chin A Paw Marijke JM, Hopman-Rock M, van Mechelen W. The effects of exercise on cognition in older adults with and without cognitive decline: a systematic review. Clin J Sport Med 2008;18:486-500.

20. Broglio SP, McCrea M, McAllister T, et al. A national study on the effects of concussion in collegiate athletes and US military service academy members: the NCAA-DoD Concussion Assessment, Research and Education (CARE) Consortium structure and methods. Sports Med 2017;47:1437-1451.

21. Carney N, Ghajar J, Jagoda A, et al. Concussion guidelines step 1: systematic review of prevalent indicators. Neurosurgery 2014;75(suppl 1):S15.

22. Katz BP, Kudela M, Harezlak J, et al. Baseline performance of NCAA athletes on a concussion assessment battery: a report from the CARE Consortium. Sports Med 2018;48:1971-1985.

23. Broglio SP, Katz BP, Zhao S, McCrea M, McAllister T; CARE Consortium Investigators. Test-retest reliability and interpretation of common concussion assessment tools: findings from the NCAA-DoD CARE Consortium. Sports Med 2018;48: $1255-1268$.

24. Kelly KC, Jordan EM, Joyner AB, Burdette GT, Buckley TA. National Collegiate Athletic Association Division I athletic trainers' concussion-management practice patterns. J Athl Train 2014;49:665-673.

25. Buckley TA, Oldham JR, Caccese JB. Postural control deficits identify lingering post concussion neurological deficits. J Sport Health Sci 2016;5:61-69.

26. Iverson GL, Gardner AJ, Terry DP, et al. Predictors of clinical recovery from concussion: a systematic review. Br J Sports Med 2017;51:941-948.

27. Hollingshead AB. Four Factor Index of Social Status. New Haven, CT; Yale UP: 1975

28. Casson IR, Viano DC, Haacke EM, Kou Z, LeStrange DG. Is there chronic brain damage in retired NFL players? Neuroradiology, neuropsychology, and neurology examinations of 45 retired players. Sports Health 2014;6:384-395.

29. Montenigro PH, Alosco ML, Martin BM, et al. Cumulative head impact exposure predicts later-life depression, apathy, executive dysfunction, and cognitive impairment in former high school and college football players. J Neurotrauma 2017;34:328-340.

30. Stone AA, Bachrach CA, Jobe JB, Kurtzman HS, Cain VS. The Science of Self-Report Implications for Research and Practice. East Sussex, UK: Psychology Press; 1999.

31. O'Connor KL, Baker MM, Dalton SL, Dompier TP, Broglio SP, Kerr ZY. Epidemiology of sport-related concussions in high school athletes: National Athletic Treatment, Injury and Outcomes Network (NATION), 2011-2012 through 2013-2014. J Athletic Train 2017;52:175-185.

32. Zuckerman SL, Kerr ZY, Yengo-Kahn A, Wasserman E, Covassin T, Solomon GS Epidemiology of sports-related concussion in NCAA athletes from 2009-2010 to 2013-2014: incidence, recurrence, and mechanisms. Am J Sports Med 2015;43: 2654-2662. 


\title{
Neurology
}

\section{Estimated age of first exposure to American football and outcome from concussion} Jaclyn B. Caccese, Zac Houck, Thomas W. Kaminski, et al.

Neurology 2020;95;e2935-e2944 Published Online before print September 9, 2020

DOI 10.1212/WNL.0000000000010672

This information is current as of September 9, 2020

\begin{abstract}
Updated Information \& Services

including high resolution figures, can be found at: http://n.neurology.org/content/95/21/e2935.full

References

This article cites 30 articles, 2 of which you can access for free at: http://n.neurology.org/content/95/21/e2935.full\#ref-list-1

Citations

This article has been cited by 1 HighWire-hosted articles: http://n.neurology.org/content/95/21/e2935.full\#\#otherarticles

Subspecialty Collections

This article, along with others on similar topics, appears in the following collection(s):

All CBMRT/Null Hypothesis

http://n.neurology.org/cgi/collection/all_cbmrt_null_hypothesis

Brain trauma

http://n.neurology.org/cgi/collection/brain_trauma

Outcome research

http://n.neurology.org/cgi/collection/outcome_research

Permissions \& Licensing

Information about reproducing this article in parts (figures,tables) or in its entirety can be found online at:

http://www.neurology.org/about/about_the_journal\#permissions

Reprints Information about ordering reprints can be found online:

http://n.neurology.org/subscribers/advertise
\end{abstract}

Neurology ${ }^{\circledR}$ is the official journal of the American Academy of Neurology. Published continuously since 1951, it is now a weekly with 48 issues per year. Copyright (C 2020 American Academy of Neurology. All rights reserved. Print ISSN: 0028-3878. Online ISSN: 1526-632X.

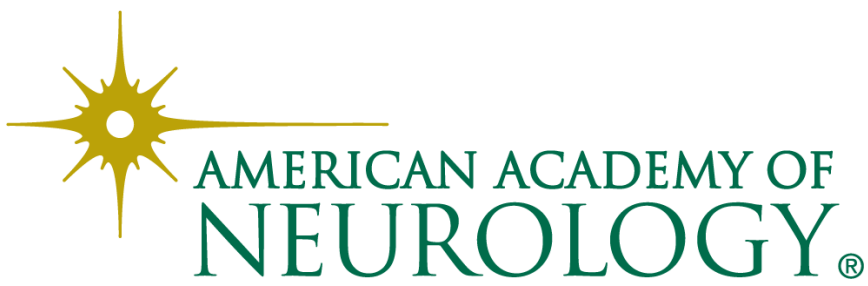

